\title{
The Correlation between General Self- Confidence and Academic Achievement in the Oral Presentation Course
}

\author{
Safaa Mohammad Al-Hebaish \\ Department of Curricula and Teaching Methods, Faculty of education, Taibah University, P.O. Box 6775, Al-Madinah \\ Al-Munawwarah, Kingdom of Saudi Arabia \\ Email: dr.safaa@mail.net.sa
}

\begin{abstract}
The study was particularly aimed at investigating the correlation between general self-confidence and academic achievement in the oral presentation course. Participants were 53 undergraduate female English majors, from Taibah University. Data was collected through a General Self-Confidence Questionnaire (GSCQ) and final evaluation grades in the Oral Presentation course. SPSS was used for analyzing data. The results revealed a positive, significant correlation between general self-confidence and academic achievement. Those who scored high in GSCQ also had high scores in the oral achievement test. Language instructors were recommended to enhance building up their students' self-confidence in order to develop their oral performance achievement.
\end{abstract}

Index Terms —oral performance, academic achievement, general self-confidence

\section{INTRODUCTION}

Language learning is a complex process (Young, 1999). It is influenced by cognitive and affective factors which constitute the main source of individual differences in foreign language learning (Tallon, 2009). According to Brown (2000) and Skehan (1989) the affective domain is the emotional side of human behaviour and it involves a variety of personality aspects such as emotion, motivation, attitude, anxiety, personality and self-confidence. Among these, selfconfidence is one of the most influential variables which affect learning. It is one of the central drives in human beings and can exercise a determining influence on a person's life, for good or bad. Dörnyei (2005, p.211) stated that the concept of self- confidence is closely related to self-esteem, both share a common emphasis on the individual's perception of his or her abilities as a person. Glenda \& Anstey (1990) explained that many researchers used the terms self-confidence, self evaluation, self worth, self appraisal, and self satisfaction interchangeably. Basically, it is a psychological and social phenomenon in which an individual evaluates him/ herself according to some values which may result in different emotional states, and which become developmentally stable, but are still open to variation depending on personal circumstances (Reasoner, cited in Rubio, 2004).

Carver et al. (1994) defined it as 'individual's overall evaluation or appraisal of themselves, whether they approve or disapprove of themselves, like or dislike themselves (Higgins, 1996, p.1073). Corsini (1994) viewed it as the way one feels about oneself or the 'sense of personal worthy and competence that people associate with their self concept' ( $\mathrm{p}$. 289). Cummings and Dunham (1989) defined it as the degree to which an individual believes him/ herself to be capable, significant, and worth (pierce \& Gardner, 2004). Coopersmith (1981) added that it is 'a set of attitudes, judgments that a person brings with him or herself when facing the world. It includes beliefs as to whether he or she can expect success or failure' (as cited in Harris, 2009,p.9). In general, it refers to attitudes and beliefs towards the self.

General self-confidence is developed during the age of childhood and emerges from the accumulation of inter and intrapersonal experiences (Harris, 2009; Brown, 1994). The literature on the sources of building general self-confidence points to self-confidence being derived from several factors. The most important factors are: (1) personal experiences; successful experiences increase the development of high self-confidence, while the experiences of failure have the opposite effect, (2) social messages received from others. Community, home, school, and peers are important for selfconfidence growth. Sending positive messages for others is thought to be detrimental to the development of high selfconfidence, whereas exposure to negative messages decreases the level of self-confidence (Glenda \& Anstey, 1990; Pierce et al., 1989; Brockner, 1988; Bandura, 1982).

Self-confidence is a personal factor that pays a supportive role in the achievement of foreign language learning. Some studies claim that no language learning activities will be carried out successfully without it (Huitt, 2004\& Khodadad, 2003, cited in Hayti 2008,; Brown, 1994). It may facilitate or debilitate academic achievement. Foreign language learners who possess general self-confidence perform well and most likely believe themselves to be capable learners. When there is low self-confidence, on the contrary, 'learners suffer from uncertainty, insecurity, fear and social distance'. (Rubio, 2007, p.7). 
Among the four language skills, the achievement of oral performance is thought to be highly correlated with selfconfidence. FL learners can't speak the language or express themselves freely and fluently without some degree of it (Brown,1994). Thus the main objective of this paper was to examine the correlation between general self-confidence and learners' academic achievement on an oral presentation test.

\section{A. Statement of the Problem}

A major challenge of foreign language instruction is to promote learners' oral communication abilities since the fundamental goal of language teaching is the production of competent speakers of the target language. In Saudi Arabia, English is taught as a compulsory knowledge subject for about seven years in general education. The only way to learn English in Saudi Arabia is in classrooms where the majority of language teachers are native speakers of Arabic. Learners spent most of their time doing grammar and vocabulary drills instead of oral practice. Developing oral communicative skills, which require learners to practice in real-life situations, is totally ignored. Moreover, learners have little opportunities to apply what they have learned in class in the outside world. As a result, they graduate from high school unable to express themselves or engage in conversation. (Rabab'h, 2005). In most Saudi universities, English language departments accept high school graduates without taking into consideration their proficiency levels in English, which in turn doubles the efforts necessarily exerted by language instructors to help them master the speaking skill.

Oral Presentation is one of the courses introduced to English majors in order to enhance their speaking abilities. Learners described it as one of the most stressful courses they have ever had. Possessing general self-confidence is thought to be helpful to learners. Self-confidence plays an essential role in affecting learners' readiness to communicate.

This paper investigated the correlation between learners' general self-confidence measured by questionnaire scores and their academic achievement on an oral presentation test, measured by test scores. The researcher selected the oral presentation course because affective variables related to second language acquisition are easier to observe in interpersonal oral communication than when reading or writing in a second language (Guiora, Brannon \& Dull, 1972; as cited in Nogueras, 1996).

\section{B. The Significance of the Study}

The current study may add information to the existing literature on how affective variables could influence the process of second language learning in a country like Saudi Arabia where opportunities to use English outside the classroom are few. It may help curriculum designers, language instructors and parents appreciate the importance of selfconfidence in the production of second language, if the results of the study reveal some association between the two variables.

\section{LITERATURE REVIEW}

To most instructors, developing learners'oral communication skills is the most challenging task in language teaching. Although practicing different communicative activities is the best way to help learners speak the language fluently, competence in the L2 may not be enough. Dörnei (2001) pointed out that learners need not only to be able to communicate but also be willing to communicate. MacIntyre et al. (2001), as cited in Brown, 2007, p.157, defined willingness to communicate as "the intention to initiate communication, given a choice".

Self-confidence is the most essential factor that determines learners' willingness to participate in oral activities in language classrooms (Yashima, Zenuk-Nishide, \& Shimizu,2004). In other words, we can say that where there is selfconfidence, there will be good communication. On the other hand, lack of self- confidence is thought to be the most dangerous barrier for effective communication. A number of studies have been carried out on the effects of selfconfidence on learners readiness to participate in classroom communicative activities (Molberg, 2010; Al-Sibai,2005; Gregersen\& Horwitz 2002; Brown, 1994). These studies revealed that self-confident learners usually take risks at speaking another language even if they do commit mistakes. They engage in different oral activities regardless of the topic discussed and the number of students in class. They learn from mistakes, work hard and eventually, they increase their language proficiency. On the other hand, low confident learners usually look away from instructor to avoid being called on. They feel uncomfortable when using the language orally because they are concerned about being criticized or disapproved of. As a result, they tend to perform less successfully (Al-sibai,2004).

The relationship between general self-confidence and academic achievement has been documented in literature. It is a controversial relationship and different studies showed conflicting results A significant number of studies reported the positive correlation of self-confidence with grades in language courses. Likewise, as high self-confidence may develop the learners'desire to communicate and help improve language proficiency, it may generate good school performance. The correlation between self-confidence and academic achievement is a dynamic one. As levels of self-confidence rise, academic achievement increases. As learners suffer from low self-confidence, academic achievement decreases. (Fook et al.,2011; Aryana, 2010; Harris, 2009; Fathi-Ashtiani et al., 2007; Al-Hattab,2006; Mahyuddin et al.,2006; Yamini \& Tahriri,2006 ;Al-Enezi,2005; Eldred et al., 2004; Lloyd \& Sullivan, 2003 ;Lockett \& Harrell, Schmidt \& padilla,2003; Walter,2003 ;Bankston \& Zhou, 2002 ; Lavoie,2002; Lawrence,1996; Brown,1994; Alatorre, 1993). Self-confidence had, in particular, an impact on learners' oral performance. It was linked to the output they produced, thus affecting L2 
communicative competence. The fear of speaking is related to low levels of confidence and resulted in lower performance (Molberg, 2010; Yahia \& Nordin,2006 ; Chang,2004; Heysook \& lee,2003; Gregersen\& Horwitz 2002; Cheng, 1999).

Contrary to the results of the above studies, some more recent studies indicated a modest or low correlation between self-confidence and academic achievement such as (Elrafei,2008; Pullmann \& Allikk, 2008; Nagar et al., 2008), and the results of other studies revealed that no correlation was found between the two variables (Ahmed et al., 2011; Zahra,2010; Kaur et.al.,2009 ;Naderi et al.,2009; Yahaya \& Ramli, 2009; Zubrick et al., 2006; Bodkin-Andrews et al.,2008; Miraei,2005; Craven \& Marsh, 2004; kimura,2002).

In conclusion, it clearly appeared from the review of this survey that there is contradiction between the results of the previously mentioned studies. The possible explanation is that the above studies were conducted in different countries on different samples, gender, levels and used different scales. It was also obvious that there did not exist much research literature on the correlation between general self-confidence and academic achievement within a Saudi context. The studies conducted on Saudi learners were very few such as Al-Hattab (2006), Al-Sibai (2005). The current paper, therefore, aimed at investigating the correlation between general self-confidence and academic oral presentation achievements of female English majors, to find out if general self-confidence had an influence on learners' oral performance.

\section{METHOD}

\section{A. Research Design}

A descriptive - correlation design was employed to find out the relationship between general self-confidence and academic achievement. The descriptive design was employed to describe the current status of the subjects in the study. The correlation study, on the other hand, was carried out to investigate the existence, or non existence of the relationship between the variables of the study in order to make predictions or suggestions (Fook et al.,2011,p.33).

\section{B. Participants}

The participants of the study were (53) undergraduate Saudi students majoring in English at Taibah University. They were female and the range of their age was from 20 to 22. They have learned English from the intermediate stage onward as a school subject like ordinary Saudi students of the same age. They joined the English Department without having much experience in speaking to native speakers / each other in English. Moreover, they had few opportunities to practice English outside the classroom walls. The English Department introduced them to some courses to help improve their speaking abilities; one of the most important was Oral Presentation. All participants enrolled in the Oral Presentation Course in the academic year of 2011. The main objective of this course was to teach learners how to construct, compose, present and deliver information through oral interaction in more fluent and correct English.

\section{Data Collection}

Data related to the objective of the study was collected from the General Self-Confidence Questionnaire constructed by Al-Enezi (1999). It was administered to participants in the first term of the academic year 2011. It consisted of 25 statements about GSC, and learners were asked to indicate their level of agreement or disagreement with each statement. The responses were scored on a five-point Likert scale response format, ranging from 'No' to 'too much'. According to the rating system of the questionnaire, the minimum score was 25 points and the maximum score was 125 points. On this questionnaire, a high score reflected a high level of GSC, whereas a low score indicated a low level of GSC.

Additionally, for the purpose of the study, academic achievement was assessed in terms of the instructors' final evaluation 'grades'. Learners' grades were obtained from the course instructor as an indicator of their achievement. In the oral presentation test, learners were tested individually. Each learner was given complete freedom to deliver a presentation about any topic and some time to prepare for the presentation. This task was supposed to be performed in front of the instructor and colleagues. Each participant was given ten minutes to deliver her presentation. The instructor evaluated according to the following criteria: fluency, accuracy, organization, conveying facts, delivery, using nonverbal language and social skills.

\section{Data Analysis}

The data acquired from the learners' scores on the self-confidence questionnaire and oral test was analyzed using SPSS (version 18.0). Descriptive statistics were calculated for better understanding of the scores obtained from the study instruments. To examine the relationship between the study variables, correlation analysis, ANOVA, T-test were carried out. The results obtained were displayed below.

\section{RESULTS}

The results of the computed descriptive statistics of the general self-confidence questionnaire revealed that the mean score of the participants was (92.41), and participants' standard deviation was (16.786). See table (1). 


\begin{tabular}{|l|l|l|l|l|l|}
\multicolumn{7}{|c|}{ TABLE (1) } \\
\hline & N & Minimum & Maximum & Mean & Std. Deviation \\
\hline Sum & 53 & 59.00 & 155.00 & 92.4151 & 16.78648 \\
\hline
\end{tabular}

It appeared from the results reported in table (2) that the mean score of the participants on oral presentation test was (81.84) and the standard deviation score was (4.89).

TABLE (2)

\begin{tabular}{|l|l|l|l|l|l|}
\hline & $\mathrm{N}$ & Minimum & Maximum & Mean & Std. Deviation \\
\hline OPT & 53 & 70.00 & 93.00 & 81.8491 & 4.89268 \\
\hline
\end{tabular}

To examine the correlation between general self-confidence and academic achievement scores, correlation analysis was conducted. The Pearson correlation coefficient, presented in Table (3), was r (.707**). The Spearman' s rank correlation coefficient was also employed to determine the correlation between the two variable. The results presented in Table (4) revealed that the correlation coefficient was $\left(.806^{* *}\right)$.

\begin{tabular}{|l|l|l|l|}
\hline \multirow{3}{*}{ GSC } & GSC & OPT \\
\cline { 2 - 4 } & Pearson Correlation & 1 & $.707(* *)$ \\
\cline { 2 - 4 } & Sig. (2-tailed) & & .000 \\
\cline { 2 - 4 } & $\mathrm{N}$ & 53 & 53 \\
\hline \multirow{3}{*}{ OPT } & Pearson Correlation & $.707(* *)$ & 1 \\
\cline { 2 - 4 } & Sig. (2-tailed) & .000 & 53 \\
\cline { 2 - 3 } & $\mathrm{N}$ & 53 & 53 \\
& \multicolumn{2}{|l|}{ ** Correlation is significant at the 0.01 level (2-tailed). }
\end{tabular}

\begin{tabular}{|l|l|l|l|l|}
\hline \multicolumn{3}{|c|}{ TABLE (4) } \\
\hline \multirow{3}{*}{ Spearman's rho } & \multirow{3}{*}{ GSC } & Correlation Coefficient & GSC & OPT \\
\cline { 3 - 5 } & & Sig. (2-tailed) & .000 & $.806(* *)$ \\
\cline { 3 - 5 } & & $\mathrm{N}$ & 53 & .000 \\
\cline { 2 - 5 } & \multirow{2}{*}{ OPT } & Correlation Coefficient & $.806(* *)$ & 53 \\
\cline { 3 - 5 } & & Sig. (2-tailed) & .000 & 1.000 \\
\cline { 3 - 4 } & & $\mathrm{N}$ & 53 & 53 \\
\hline
\end{tabular}

The findings above indicated that the participants' scores on the general self-confidence questionnaire correlated positively with oral test scores. It appeared that general self-confidence could affect the quality of oral performance.

The participants were divided in two groups according to the scores they acquired on the general self-confidence questionnaire: the higher self-confidence group and the lower self-confidence group. The ANOVA analysis was run, using self-confidence as the independent variable (high \& low) and oral performance as the dependent variable. The results of the analysis revealed that self-confidence had a significant effect on the participants' oral performance $\mathrm{F}$ $(20.82)=\mathrm{P}<0.01$.

Further, correlation analysis was employed to examine if there was a significant correlation between possessing high levels of self-confidence and high scores in the oral presentation test. The results, reported in table (5), showed a statistically positive correlation at the level of $\mathrm{P}<0.01$. The positive correlation showed that the higher the participants' level of general self-confidence, the higher were their oral presentation scores and conversely participants with low selfconfidence had lower scores. In other words, the participants' level of general self-confidence was a significant predictor for their academic achievement.

\begin{tabular}{|ll|l|l|l|l|l|}
\hline group_s & $\mathrm{N}$ & Mean & Std. Deviation & Std. Error Mean & Spearman's rho \\
\hline \multirow{2}{*}{$\begin{array}{l}\text { grpou p } \\
-\end{array}$} & $59-79$ & 13 & 1.1538 & .55470 & .15385 & $.749(* *)$ \\
\cline { 2 - 6 } & $107-155$ & 13 & 3.4615 & .66023 & .18311 & \\
\hline
\end{tabular}

The findings mentioned above highlighted the importance of self-confidence in speaking a foreign language. Selfconfident learners are ready to speak in public. They work hard, perform well and accordingly, achieve academic progress. On the contrary, the issue of developing oral communication skills becomes problematic when learners suffer from a lack of self-confidence. Low confident learners feel uncomfortable, afraid and frustrated in the classroom. As a result, they tend to perform with less effectiveness and satisfaction, which is affecting their academic achievement in general.

\section{CONCLUSION}


The study examined the correlation between general self-confidence and achievement in the oral performance test of undergraduate female English majors. The results indicated a positive significant correlation between the two variables. The more self confident learners were, the higher were their scores in the oral test. Highly self-confident learners were ready to try to speak in front of others. Lack of general self-confidence, on the other hand, resulted in lack of interest to strive for high quality oral performance. Less confident learners were not certain of their abilities. They tended to try less which in turn leaded to low levels of achievement. The findings of the study also highlighted the importance of promoting general self-confidence among language learners in order to develop their oral proficiency. Therefore, language instructors are recommended to focus on building their students' self-confidence through creating a supportive classroom environment that encourages them to speak and participate in oral activities without fear. They can help learners recognize their fears and help them learn to deal with them. They can support positive thinking and fight negative views and beliefs. During oral activities, they should maintain a relaxed and humorous atmosphere; design interesting activities give more time and opportunities and concentrate on the positive.

\section{REFERENCES}

[1] Ahmed, J et al. (2011). The Relationship between Self Concept and Response to Word Students' Academic Achievement among Students Learners in University Putra Malaysia. International Journal of Instructio.4 (2), 23-38.

[2] Alatorre, S. (1993). Different Patterns of Achievement among Asian-American Adolescents Journal of Youth and Adolescence, 22(4), 07-423

[3] Al-Enezi, F. (2005). Academic Achievement and its Relationship with Anxiety, Self- Esteem, Optimism and Pessimism in Kuwaiti Students. Social Behaviour and Personality, 33(1), 95-104.

[4] Al-Hattab, A. (2006). Self-esteem and Writing Achievement of Saudi EFL Students in Secondary Schools. Master Thesis. Taibah University. Saudi Arabia

[5] Al-Sibai, D. (2005). L2 Anxiety of Saudi Female University Students Enrolled in Speaking Courses. Retrieved on July 26,2011 from http://faculty.ksu.edu.sa/dinaalsibai/Research\%20Papers/13. \%20Speech \%20Anxiety.pdf

[6] Al-Sibai, D. (2004). Promoting Oral Fluency of Second Language Learners. Retrieved on October 13,011 from http://faculty.ksu.edu.sa/dinaalsibai/Research\%20Papers/12.\%20Oral\%20Fluency\%20Lit\%20Review.pdf

[7] Aryana, M. (2010). Relationship between Self-Esteem and Academic Achievement amongst Pre-University Students. Journal of Applied Sciences, 10 (20), 2474-2477

[8] Bandura, A. (1982). Self-Efficacy Mechanism in Human Agency. American Psychologist, 37 (2), 122-147.

[9] Bankston, C. \& Zhou, M. (2002). Being Well vs. Doing well: Self-Esteem and School Performance among Immigrant and Non-Immigrant Racial and Ethnic Groups. International Migration Review, 36 (2), 389-415.

[10] Bodkin-Andrews, G. et al. (2008). The Failure of General Self-Esteem: Self-Esteem's Aggravating Affect on Racial Discrimination's Relation to Achievement. Paper Presented at the Australian Association for Research in Education, Brisbane, November 2008

[11] Brockner, J. 1988. Self-Esteem at Work: Theory, Research, and Practice. Lexington, MA: Lexington Books.

[12] Brown, D. (2007). Principles of Language Learning and Teaching. Fifth Edition. Pearson Education, Inc.

[13] Brown, H. (2000). Personality Factors. Principles of Language Learning and Teaching. New York: Pearson education.

[14] Brown, H. (1994). Principles of Language Learning and Teaching. Englewood Cliffs, NJ. Prentice-Hall.

[15] Craven, R. \& Marsh, H. (2004). The Challenge for Counsellors: Understanding and Addressing Indigenous Secondary Students' Aspirations, Self-concepts and Barriers to Achieving their Aspirations. Australian Journal of Guidance and Counselling, 14(1), 16-33

[16] Chang, Y. (2004). The Effect of Anxiety among EFL Learners in Taiwan. Retrieved on October 7, 2011 from: http://it.snhu.edu/efl537/changyaling/The\%20effect\%20of \%20anxiety\%20among\%20EFL\%20learners\%20in\%20Taiwan.doc

[17] Cheng, Y. (1999). Language Anxiety: Differentiating Writing and Speaking Components. Language Learning 49:3, 417-446.

[18] Corsini, R. (ED). Encyclopaedia of Psychology. (2 ${ }^{\text {nd }}$ Edition, Vol. 3). New York. John Wiley \& Sons.

[19] Dörnei, Z. (2001). Motivational Strategies in the Language Classroom, Cambridge University Press, Cambridge, UK.

[20] Dörnyei, Z. (2005). The Psychology of the Language Learner: Individual differences in Second Language Acquisition. Routledge

[21] Eldred, J. et al. (2004). Catching Confidence. NIACE www.niace.org.uk

[22] Elrafei, S. (2008). The Relationship between Self-Esteem and Gender, Grade Level and Academic Achievement, in Secondary Schools' Classes in Lebanon. Doctoral Dissertation. University of Leicester.

[23] Fathi-Ashtiani, A et al. (2007). Relationship between Self-Concept, Self-Esteem, Anxiety, Depression and Academic Achievement in Adolescents. Journal of Applied Science, 7, 995-1000.

[24] Fook, C et al. (2011). Analyzing Factors Associated with Students" Oral Test Performance. The International Journal of Educational and Psychological Assessment. Vol. 9(1): 27-46

[25] Glenda, L \& Anstey, B. (1990). The Relationship of self-Esteem and Classroom Communicative Potential in Early French Immersion. Master Thesis. Memorial University of Newfoundland.

[26] Gregersen, T.\& Horwitz, E. (2002), Language Learning and Perfectionism: Anxious and Non- Anxious Language Learners' Reactions to their Own Oral Performance. The Modern Language Journal 86 562-570.

[27] Harris, S. (2009). The relationship Between Self-Esteem and Academic Success among African American Students in the Minority Engineering Program at a Research Extensive University in the Southern Portion of the United States. Doctoral Dissertation. Louisiana State University.

[28] Hayati, M. (2008). The Relationship between Self-esteem and Listening Comprehension of EFL Students Retrieved on July 24,2011 from: http://bibliotecavirtualut.suagm.edu/Glossa2/Journal /jun2008/ The_Relationship_between_Self-esteem.pdf 
[29] Higgins, E. (1996). The 'Self-Digest': Self- Knowledge Serving Self-Regularity Functions. Journal of Personality and Social Psychology, 30, 1-46.

[30] Kaur, J et.al. (2009). Home Environment and Academic Achievement as Correlates of Self-Concept among Adolescents. Stud Home Comm Sci, 3(1): 13-17

[31] Kimura, M. (2002). Affective Factors of Japanese EFL Learners at Junior College in the Oral Communication Tasks. Paper Presented at the Annual Meeting of The American Educational Research Association, USA. (ERIC Document Reproduction Service No. ED 471470)

[32] Lavoie, R. (200). Self-Esteem: The Cause and Effect of Success for the Child with Learning Differences. Retrieved on July 30, 2011 from: http://www.ricklavoie.com/selfesteemart.html

[33] Lawrence, D. (1996). Enhancing Self-Esteem in the Classroom. London: PCP Ltd.

[34] Lloyd, R. \& Sullivan, F. (2003), Measuring Soft Outcomes and Distance Travelled. A Methodology for Developing A Guidance Document. Department of Work and Pensions.

[35] Lockett, C. \& Harrell, J.(2003). Racial Identity, Self-Esteem, and Academic Achievement: too Much Interpretation, too Little Supporting Data. Journal of Black Psychology, 29(3), 325-336

[36] Mahyuddin, R. Et al. (2006). The Relationship between Sstudents' Self-Efficacy and Their English language Achievement. Pendidik dan Pendidikan Journal, 21, 61-71

[37] Miraei, R. (2005). The Relationship between Self esteem, Self Concept and Academic Achievement among Junior of High School 'Students. University of Tarbiat Moallem, Tehran, Iran.

[38] Molberg, H. (2010). The Consequence of Motivation and Linguistic Self-Confidence in Relation to Pupil'Oral Interaction. Master Thesis. University of Troms $\varnothing$.

[39] Naderi ,H et al. (2009). Self-Esteem, Gender and Academic achievement of Undergraduate Students. American Journal of Scientific Research, 3: 26-37

[40] Nagar,S. et al. ( 2008). Self-Esteem among Rural Adolescent Girls in kangra District of Himachal Pradesh. Anthropologist, 10: 151-154

[41] Nogueras, C. (1996). Self-Esteem and Oral Communicative Language Proficiency in the Puerto Rican Teaching-Learning Process. Retrieved on July 3, 2011 from http://bibliotecavirtualut.suagm.edu/Glossa/Journal/vol1num2/Self_esteem_communicative_proficiency.pdf.

[42] Pierce, J. \& Gardner, D. (2004). Self-Esteem Within the Work and Organisational Context: A Review of the OrganizationBased Self- Esteem literature. Journal of Management. 30 (5), 591-622.

[43] Pierce, J et al. (1989). Organization-Based Self-Esteem: Construct Definition Measurement and Validation. Academy of Management Journal, 32, 622-648.

[44] Pullmann, H \& Allkil, J. (2008). Relations of Academic and General self-Esteem to School Achievement. Personal Individual Differences, 45,559-564

[45] Rabab'h, G. (2005). Communication Problems Facing Arab Learners of English. Journal of Language and Learning, 3 (1), 180-197

[46] Rubio, F. (2007). Self-Esteem and Foreign Language Learning. Cambridge Scholars Publishing.

[47] Schmidt, J. \& Padilla, B. (2003). Self-Esteem and Family Challenge: An Investigation of their Effects on Achievement. Journal of Youth and Adolescence, 32, 37-46.

[48] Skehan, P. (1989). Individual Differences in Second Language Learning. London: Edward Arnold.

[49] Tallon, M. (2009). Foreign Language Anxiety and Heritage Students of Spanish: A Quantitative Study. Foreign Language Annals, 42(1), 112-137.

[50] Walter, W. (2003). The Re-evaluation of the Relationships among Academic Performance, Academic Achievement, Social Acceptance and the Self-Esteem of Third and Sixth Grade Students. Dissertation Abstract. Int., 64, 8-10.

[51] Yahaya, A \& Ramli, J. (2009). The Relationship between Self-Concept and Communication Skills towards Academic Achievement among Secondary School Students in Johor Bahru. International Journal of Psychological Studies, 1 (2), 25-34

[52] Yamini, M. \& Tahriri, A. (2006). On the Relationship between Foreign Language Classroom Anxiety and Global Self-Esteem among Male and Female Students at Different Educational Levels. International Journal of Applied Linguistics 9(1), March.

[53] Yashima, T., Zenuk-Nishide,L. \& Shimizu, K. (2004). The Influence of Attitudes and Affect on Willingness to Communicate and Second Language Communication. Language Learning, 54, 119-152.

[54] Young, D. (1999). Creating a low anxiety Classroom Environment: What Does Language Anxiety Research Suggest ? Modern Language Journal, 75, 426-4

[55] Zahra, A. (2010). Relationship between Self-Concept and Academic Achievement of Female Bachelor Degree Students. Doctoral Dissertation. University Institute of Education and Research. Rawalpindi, Pakistan

[56] Zubrick, S. et al. (2006). The Western Australian Aboriginal Child Health Survey: Improving the Educational Experiences of Aboriginal Children and Young People. Perth: Curtin University of Technology and Telethon Institute for Child Health Research.

Safaa Mohammad Al-Hebaish is a faculty member, Taibah University. Currently, she teaches courses related to language learning, TEFL and methodology in language teaching. Her research interests include second language learning, E-learning and quality assurance and academic accreditation studies. Correspondence should be made to: Department of Curricula and Teaching Methods, Faculty of education, Taibah University, P.O. Box 6775, Al-Madinah Al-Munawwarah, Kingdom of Saudi Arabia. 